Tropical Journal of Pharmaceutical Research October 2021; 20 (10): 2089-2097

ISSN: $1596-5996$ (print); 1596-9827 (electronic) (C) Pharmacotherapy Group, Faculty of Pharmacy, University of Benin, Benin City, 300001 Nigeria.

\title{
Clinico-toxicological effects of ceftriaxone after intramuscular administration of graded doses in Basenji dogs
}

\author{
Ukamaka U Eze ${ }^{1 *}$, Ifeanyi G Eke ${ }^{2}$, Aruh O Anaga ${ }^{2}$, Elias Abah², Ikechukwu J \\ Udeani $^{3}$, Ekene V Ezenduka ${ }^{4}$, Chuka Ezema ${ }^{5}$, Boniface M Anene ${ }^{1}$, Isaac U \\ Asuzu $^{2}$ \\ ${ }^{1}$ Department of Veterinary Medicine, ${ }^{2}$ Department of Veterinary Physiology and Pharmacology, Faculty of Veterinary Medicine, \\ ${ }^{3}$ University of Nigeria Veterinary Teaching Hospital, ${ }^{4}$ Department of Veterinary Public Health and Preventive Medicine, \\ ${ }^{5}$ Department of Animal Health and Production, Faculty of Veterinary Medicine, University of Nigeria, Nsukka, Nigeria
}

*For correspondence: Email: ukamakauchenna.eze@unn.edu.ng; Tel: +234-8063529700

\begin{abstract}
Purpose: The recent ceftriaxone-induced anaemia and mortalities at the dose of $50 \mathrm{mg} / \mathrm{kg}$ in Veterinary Teaching Hospital, University of Nigeria prompted this study which sought to assess the clinicotoxicological effects of ceftriaxone (CFZ) after intramuscular administration of graded doses in Basenji dogs.

Methods: The effects of CFZ on the haematological indices, physiological parameters, liver and kidney functions were assessed in 4 group of dogs $(n=4)$ designated $A-D$. They were given CFZ intramuscularly for 21 days at doses of 12, 25 and $50 \mathrm{mg} / \mathrm{kg}$ for groups $A, B, C$, respectively, while the control (group D) received the diluent (lignocaine $0.2 \mathrm{~mL}$ )

Results: The mean pulse and heart rate of dogs in group $C$ were significantly $(p<0.05)$ higher than those of group $A, B$ and $D$. Significant $(p<0.05)$ decrease in red blood cell count $(R B C)$, haemoglobin concentration $(\mathrm{Hb})$ and packed cell volume $(\mathrm{PCV})$ was observed in group $C$ on days 7 and 14 , while on day 21 , these parameters were significantly $(p<0.05)$ higher in group $D$ than in the treated groups. On day 14 of CFZ administration, the alanine transaminase (ALT), aspartate aminotransferase (AST) and alkaline phosphatase $(A L P)$ activities of dogs in group $C$ was significantly $(p<0.05)$ elevated than the control group.

Conclusion: These findings suggest that CFZ, at the doses of $12.5-25 \mathrm{mg} / \mathrm{kg}$, appears safe in dogs as most of the adverse effects observed are reversed following the withdrawal of the drug on day 28. However, CFZ at $50 \mathrm{mg} / \mathrm{kg}$ causes anaemia, tachycardia and bilateral paralysis of the hind limbs which did not revert to normal after one week; hence, it is not recommended for use in dogs at this dose.
\end{abstract}

Keywords: Ceftriaxone, Dogs, Haematology, Physiological parameters, Toxicity

This is an Open Access article that uses a funding model which does not charge readers or their institutions for access and distributed under the terms of the Creative Commons Attribution License (http://creativecommons.org/licenses/by/4.0) and the Budapest Open Access Initiative (http://www.budapestopenaccessinitiative.org/read), which permit unrestricted use, distribution, and reproduction in any medium, provided the original work is properly credited.

Tropical Journal of Pharmaceutical Research is indexed by Science Citation Index (SciSearch), Scopus, International Pharmaceutical Abstract, Chemical Abstracts, Embase, Index Copernicus, EBSCO, African Index Medicus, JournalSeek, Journal Citation Reports/Science Edition, Directory of Open Access Journals (DOAJ), African Journal Online, Bioline International, Open-J-Gate and Pharmacy Abstracts

\section{INTRODUCTION}

Antimicrobial agents have several groups that are used in medicine and amongst all of them, the cephalosporins are one of the most important group that has been put into use because of their broad-spectrum efficacy in the management of infections caused by most Gram-negative and 
Gram-positive bacteria [1]. The Ceftriaxone (CFZ) sodium sub-group of cephalosporins is a semi-synthetic third generation cephalosporin which has activity in the presence of some betalactamases of Gram-negative and Grampositive bacteria. The drug has been used in the treatment of severe bacterial infections including meningitis, syphilis, late-stage leptospirosis, acute bacterial otitis, osteomyelitis, respiratory and urinary tract infections [2].

Although CFZ is a drug of extreme importance, it has its own down side as some adverse reactions have been tied to its use especially when taken daily for 7 days and beyond. CFZ has been shown to be the second most common drug that causes drug induced immune haemolytic anaemia which is highly fatal in children [3]. It has also been reported to have induced acute hepatitis, hepatocellular injuries, autoimmune hemolytic anemia, and erythroblastocytopenia in an 80-year-old patient shortly after taking the drug [4]. Other reported adverse effect in humans include; local reactions like pain, induration and tenderness at the site of injection; other haematologic effects such as eosinophilia, thrombocytosis, leucopenia, neutropenia, lymphopenia, thrombocytopenia and prolonged prothrombin time [5].

Generally, cephalosporins is used in veterinary medicine because of its bactericidal activity against both Gram-positive and Gram-negative bacteria of clinical importance. In Veterinary medicine, CFZ has been used as extra-label drug in the treatment of different animal bacterial diseases such as mastitis in cows, staphylococcal endocartitis and lower urinary tract infection in dogs amongst others [6]. There is no veterinary preparation of the drug which has led to a number of studies on the efficacy of CFZ in veterinary medicine [6]. As an extra-label drug, the accurate adverse effect profile has not been determined. With the development of antimicrobial resistance in frequently used antibiotics, efforts have been made by veterinary clinicians to use extra labeled antibiotics. Recently, two exotic dogs brought to the University of Nigeria, Nsukka Veterinary Teaching Hospital died shortly after IM administration of $50 \mathrm{mg} / \mathrm{kg} \mathrm{CFZ} \mathrm{with} \mathrm{obvert} \mathrm{signs}$ of anaemia. Therefore, it became imperative to evaluate the clinico-toxicological effects of CFZ.

\section{EXPERIMENTAL}

\section{Ethical consideration}

The protocol for this study was approved by Experimental Animal Ethics Committee of the
Faculty of Veterinary Medicine, University of Nigeria, Nsukka (approval no. UNFVM/11/17/009) and in compliance with the protocol of National Institute of Health (NIH) guidelines [7].

\section{Animals}

Sixteen (16) clinically healthy female dogs between the ages of 12 to 14 months were used for the study. The dogs were housed individually in metal cages in the Department of Veterinary Medicine, University of Nigeria, Nsukka, Nigeria in a fly-proof dog kennel. The dogs were fed with standard pelletized dried dog food (Diamond Pet Foods $^{\circledR}$, USA) twice daily and tap water was provided ad libitum throughout the period of the study. During the 3 weeks acclimatization period, the dogs were de-wormed using Wormrid $^{\odot}$ (combination of febentel, pyrantel palmoate and praziquantel) and vaccinated against rabies and DHLPP (distemper, parvoviral enteritis, parainfluenza, infectious canine hepatitis and leptospirosis polyvalent vaccine) (Bioveta, Czech Republic) and then screened for haemoparasites before the commencement of the experiment.

\section{Drugs}

Rocephin $^{\circledR}$ (Roche Ltd, Switzerland) containing CFZ sodium (1g per vial) was procured from a registered pharmaceutical premise in Nigeria. For intramuscular injection, $3.5 \mathrm{ml}$ of lignocaine hydrochloride was included in each vial as reconstituting solvent.

\section{Experimental design}

The CFZ doses were as reported by Eke et al [8]. The dogs were assigned to 4 groups $A-D$. Groups A - C were administered 12.5, 25 and 50 $\mathrm{mg} / \mathrm{kg}$, CFZ respectively while group D was administered $0.2 \mathrm{~mL}$ of diluent (lignocaine). CFZ was given to all the experimental groups intramuscularly once daily for 21 days.

The parameters assessed were clinical signs, change in body weight (Bwt), heart rate (HR), pulse rate (PR) and respiratory rate (RR), packed cell volume (PCV), haemoglobin concentration $(\mathrm{HbC})$, red blood count (RBC), total white blood cell counts(TWBC), differential white blood cell counts (DWBC), alanine aminotransaminase $(A L T)$, alkaline phosphatase (ALP) and aspartate aminotransaminase (AST), and serum levels of total and direct bilirubin, total protein, albumin, globulin, blood urea nitrogen (BUN), creatinine and uric acid levels. 


\section{Blood sample collection}

Following drug administration, blood samples were collected on days $7,14,21$ and on day 28 . Four millilitres $(4 \mathrm{~mL})$ of blood were collected from each dog through the cephalic vein using a 21 -guage needle. One millilitre $(1 \mathrm{~mL})$ of the blood was then added into pre-labelled sample bottle containing Ethylene diamine tetra acetic acid (EDTA) and then rocked gently to ensure proper mixture of blood with the anticoagulant for haematological analysis. The remaining $3 \mathrm{~mL}$ of blood were allowed to clot and centrifuged at $1,500 \mathrm{rpm}$ for $15 \mathrm{~min}$ to harvest the serum. The sera were stored frozen until required for analyses.

\section{Recording of physiologic parameters}

The body weights of the dogs were determined using a weighing balance. The temperature, respiratory, heart and pulse rates were monitored and recorded using Veterinary Mutiparameter monitor (Technocare medisystem, Surat, India) on days $7,14,21$ and 28 of ceftriaxone administration. Pulse and heart rates were measured before and within 1 to $5 \mathrm{~min}$ after ceftriaxone administration. At the time of recording, all the dogs were restrained manually and maintained at standing position throughout the recording.

\section{Determination of haematological parameters}

The red blood cells (RBC), packed cell volume $(\mathrm{PCV})$ and haemoglobin $(\mathrm{Hb})$ concentration were determined using a haemocytometer [9], microhaematocrit methods [9] and cyanomethaemoglobin method [10] using SP6500 UV spectrophotometer (PYE UNICAM, England), respectively. TWBC was performed manually using the improved Neubauer haemocytometer method [9].

\section{Evaluation of biochemical parameters}

The analysis of serum levels of alanine aminotransaminase (ALT), alkaline phosphatase (ALP) \& aspartate aminotransaminase (AST), and serum levels of total and direct bilirubin, total protein, albumin and globulin, blood urea nitrogen (BUN), Creatinine and uric acid were performed using their specific commercial kits (Dialab, Wiener Neudorf, Austria), following the manufacturer's instructions. The absorbance of each parameter analyzed was determined using a spectrophotometer (SP6-500UV spectrophoto- meter (PYE UNICAM, England) at their specific wavelength.

\section{Statistical analysis}

Data obtained are presented as Means \pm SEM and were subjected to Two Way Analysis of Variance (ANOVA) using Graphpad Prism statistical software Version 5.02 [La Jolla, California, USA, (www.graphpad.com)]. Variant means were separated using Bonferroni's multiple comparison tests. The alpha value of significance was set at the probability level of < 0.05 .

\section{RESULTS}

The side effects CFZ in dogs observed in this study includes; local pain at site of injection, pale mucous membrane, mucopurulent eye discharge, diarrhea, bilateral paralysis of the hind limb, dark brown-coloured urine and loss of hair. These untoward effects were only seen in group C $(50 \mathrm{mg} / \mathrm{kg})$ except loss of hair and pain at the site of injection which were also observed in groups $A$ and $B$ by the second week of CFZ administration.

\section{Heart and pulse rates}

Following CFZ administration, a spike was observed in the values of pulse and heart rates within the first five minutes in all the groups receiving the drug after which they returned to normal after one hour. The mean pulse and heart rates of dogs in group $C$ were significantly $(p<$ 0.05 ) higher than those of dogs in group $A, B$ and $D$, as shown in Figure 1, and this trend was observed throughout the experimental period.

\section{Hematology}

The mean values of RBC, PCV and $\mathrm{HB}$ concentration of dogs in group $C(50 \mathrm{mg} / \mathrm{kg})$ was significantly $(p<0.05)$ decreased compared to groups A $(12.5 \mathrm{mg} / \mathrm{kg}), B(25 \mathrm{mg} / \mathrm{kg})$ and the control group D on day 7 and 14 as shown in Table 1. On day 21, dogs in group $D$ had significantly $(p<0.05)$ higher red blood cell count than groups A, B and C. A significant $(p<0.05)$ decrease in the mean RBC values of dogs in group C was observed on day 28 (1 week after withdrawal of ceftriaxone).

\section{Total and differential white blood cell count}

Following CFZ administration, there was a significant $(p<0.05)$ decrease in the mean 

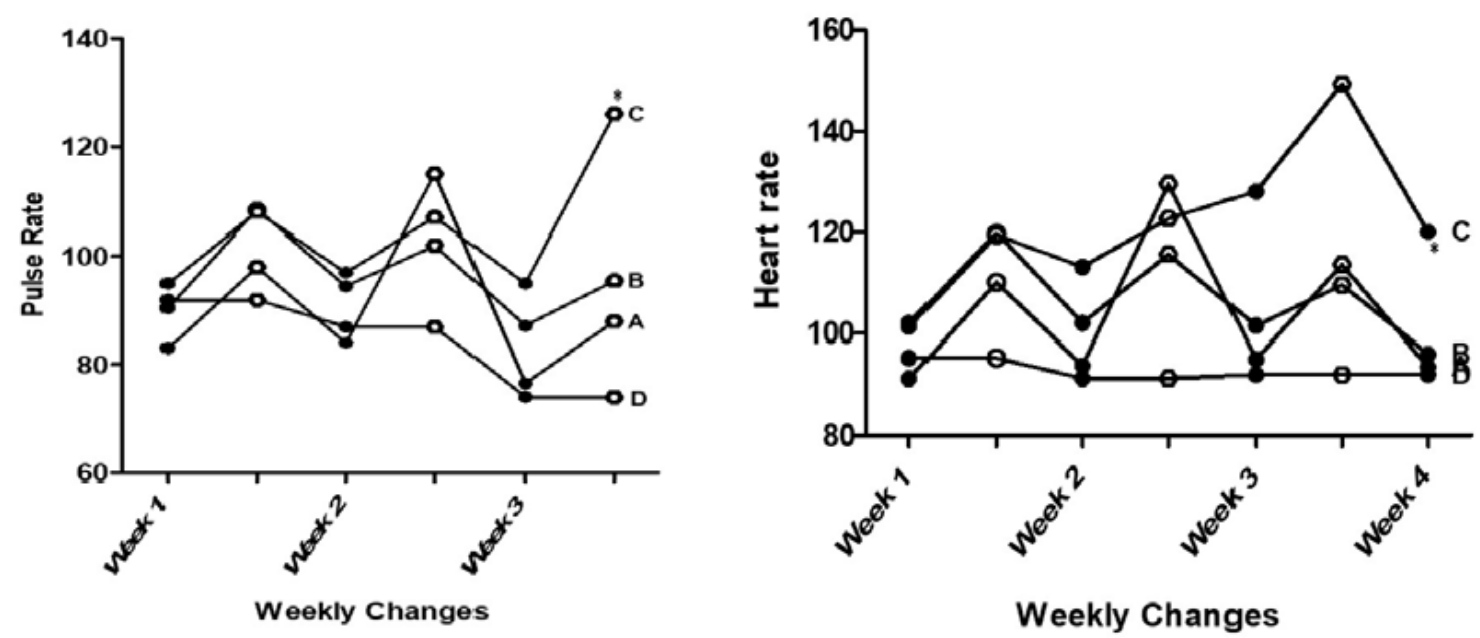

Figure 1: Effect of ceftriaxone on pulse and heart rates of dogs. *significance

Table 1: Effects of ceftriaxone administration on the RBC, PCV and $\mathrm{Hb}$ concentration of dogs

\begin{tabular}{|c|c|c|c|c|}
\hline \multirow[t]{2}{*}{ Parameter } & \multicolumn{4}{|c|}{ Days of ceftriaxone administration } \\
\hline & 7 & 14 & 21 & 28 \\
\hline \multicolumn{5}{|l|}{$R B C\left(\times 10^{6} / \mu l\right)$} \\
\hline A & $6.565 \pm 0.749^{a}$ & $5.220 \pm 0.189^{a}$ & $4.033 \pm 0.234^{a}$ & $6.695 \pm 0.419^{a}$ \\
\hline B & $6.781 \pm 1.262^{\mathrm{a}}$ & $5.358 \pm 0.739^{a}$ & $3.980 \pm 0.330^{\mathrm{a}}$ & $5.650 \pm 0.401^{a}$ \\
\hline $\mathrm{C}$ & $4.033 \pm 0.243^{b}$ & $3.980 \pm 0.330^{b}$ & $2.828 \pm 0.421^{\mathrm{a}}$ & $2.213 \pm 1.278^{b}$ \\
\hline D & $6.090 \pm 0.131^{a}$ & $6.213 \pm 0.093^{a}$ & $6.240 \pm 0.728^{b}$ & $6.283 \pm 0.044^{a}$ \\
\hline \multicolumn{5}{|l|}{$P C V(\%)$} \\
\hline$A$ & $42.00 \pm 3.24^{a}$ & $43.00 \pm 2.24^{a}$ & $36.25 \pm 3.11^{\mathrm{a}}$ & $40.25 \pm 2.50^{a}$ \\
\hline$B$ & $44.25 \pm 3.24^{a}$ & $42.88 \pm 2.95^{\mathrm{a}}$ & $32.25 \pm 2.84^{\mathrm{a}}$ & $40.50 \pm 2.40^{a}$ \\
\hline C & $31.67 \pm 3.71^{\mathrm{b}}$ & $29.50 \pm 2.78^{b}$ & $28.00 \pm 1.00^{a}$ & $18.67 \pm 1.06^{b}$ \\
\hline D & $47.67 \pm 0.88^{a}$ & $48.05 \pm 0.88^{a}$ & $48.33 \pm 1.20^{b}$ & $48.67 \pm 0.33^{a}$ \\
\hline \multicolumn{5}{|l|}{ Hb conc. $(g / d l)$} \\
\hline A & $16.54 \pm 1.73^{a}$ & $17.68 \pm 1.16^{a}$ & $13.23 \pm 1.34^{\mathrm{a}}$ & $15.27 \pm 1.40^{\mathrm{a}}$ \\
\hline B & $17.52 \pm 1.45^{a}$ & $19.81 \pm 1.50^{a}$ & $12.07 \pm 0.38^{a}$ & $13.21 \pm 1.27^{a}$ \\
\hline C & $12.77 \pm 0.44^{b}$ & $12.61 \pm 0.72^{b}$ & $8.420 \pm 0.44^{a}$ & $7.287 \pm 1.06^{b}$ \\
\hline $\mathrm{D}$ & $18.50 \pm 0.55^{a}$ & $18.05 \pm 0.42^{\mathrm{a}}$ & $17.95 \pm 0.28^{b}$ & $18.07 \pm 0.07^{a}$ \\
\hline
\end{tabular}

leucocytes, neutrophil and lymphocyte counts of dogs in groups $\mathrm{C}$ on days 14, 21 and 28 as shown in Table 2.

Effect of 21-day intramuscular ceftriaxone administration on serum liver enzyme activities in dogs

The effect of CFZ on the liver enzyme activities is shown in Table 3 . The treated groups $(A, B, C)$ showed significant $(p<0.05)$ decrease in ALT activity compared to the control group on day 7 . However, on day 14 and 21, ALT activity of dogs in group $C$ was significantly $(p<0.05)$ higher than those of dogs in groups $A$ and $B$.
Day 28 showed, serum ALT levels significantly ( $p$ $<0.05)$ higher in dogs in group $A, B$ and $C$ compared to the control group $D$. There was a significant $(p<0.05)$ elevation in the serum ALP activity of dogs in all the treated groups on day 14 when compared to the control group. However, by the $21^{\text {st }}$ and $28^{\text {th }}$ day, the serum ALP level was significantly $(p<0.05)$ lower in the treated groups when compared to the control group. The 25 and $50 \mathrm{mg} / \mathrm{kg}$ ceftriaxone treated groups showed significantly $(p<0.05)$ elevated activity of serun AST on days 14 to 28 when compared to the control dogs. On day 14 of CFZ administration, total seum protein of dogs in group $C$ was significantly $(p<0.05)$ lower than those of group A, B and D. However, on days 21, the total serum protein of dogs in groups $A$ and $B$ 
Table 2: Effects of experimental ceftriaxone administration on the leucocyte, neutrophil and lymphocyte counts of dogs

\begin{tabular}{|c|c|c|c|c|}
\hline \multirow[t]{2}{*}{ Parameter } & \multicolumn{4}{|c|}{ Days of ceftriaxone administration } \\
\hline & 7 & 14 & 21 & 28 \\
\hline \multicolumn{5}{|c|}{ Leucocytes $\left(\times 10^{3} / \mu L\right)$} \\
\hline A & $21.18 \pm 0.86$ & $21.23 \pm 0.85^{\mathrm{a}}$ & $19.85 \pm 0.86^{a}$ & $17.88 \pm 0.50^{a}$ \\
\hline B & $22.06 \pm 0.61$ & $21.42 \pm 0.73^{a}$ & $18.21 \pm 0.33^{a}$ & $16.19 \pm 0.91^{a}$ \\
\hline C & $20.00 \pm 0.92$ & $14.89 \pm 0.06^{b}$ & $9.03 \pm 0.90^{\mathrm{b}}$ & $5.19 \pm 0.32^{\mathrm{b}}$ \\
\hline D & $22.23 \pm 0.28$ & $22.30 \pm 0.90^{a}$ & $22.09 \pm 0.57^{\mathrm{a}}$ & $22.17 \pm 0.29^{a}$ \\
\hline \multicolumn{5}{|c|}{ Lymphocytes (x $\left.10^{3} / \mu \mathrm{l}\right)$} \\
\hline A & $6.60 \pm 0.49$ & $7.02 \pm 0.84^{\mathrm{a}}$ & $5.90 \pm 0.34^{a}$ & $5.85 \pm 0.80^{a}$ \\
\hline B & $7.02 \pm 0.93$ & $6.55 \pm 0.68^{a}$ & $6.90 \pm 0.19^{a}$ & $5.43 \pm 0.25^{a}$ \\
\hline C & $7.43 \pm 0.03$ & $3.17 \pm 0.84^{b}$ & $3.37 \pm 0.31^{\mathrm{b}}$ & $1.40 \pm 0.10^{\mathrm{b}}$ \\
\hline $\mathrm{D}$ & $8.17 \pm 0.75$ & $8.60 \pm 0.44^{a}$ & $8.63 \pm 0.37^{a}$ & $7.86 \pm 0.65^{\mathrm{a}}$ \\
\hline \multicolumn{5}{|c|}{ Neutrophils $\left(\times 10^{3} / \mu l\right)$} \\
\hline A & $14.60 \pm 0.73$ & $13.68 \pm 0.16^{a}$ & $13.23 \pm 0.34^{a}$ & $12.27 \pm 0.40^{a}$ \\
\hline B & $15.83 \pm 0.24$ & $14.81 \pm 0.50^{\mathrm{a}}$ & $11.07 \pm 0.38^{a}$ & $11.21 \pm 0.27^{a}$ \\
\hline C & $13.60 \pm 0.22$ & $7.61 \pm 0.72^{\mathrm{b}}$ & $6.20 \pm 0.44^{b}$ & $4.287 \pm 0.06^{b}$ \\
\hline $\mathrm{D}$ & $14.47 \pm 0.01$ & $13.95 \pm 0.42^{\mathrm{a}}$ & $14.95 \pm 0.28^{a}$ & $14.07 \pm 0.07^{a}$ \\
\hline
\end{tabular}

were significantly $(p<0.05)$ higher than those of dogs in groups $C$ and D. On days 14,21 and 28 , the serum albumin level of dogs in group $C$ was significantly $(p<0.05)$ lower when compared to groups A, B and D. There was a significant $(p<$ 0.05 ) decrease in the serum globulin concentration in dogs in group $C$ on days 7 and 14 when compared to dogs in groups A, B and the control group (group D); however, on days 21 and 28 , there was a significant $(p<0.05)$ increase in the serum globulin concentration of dogs in group A when compared to control group D. On day 7 of CFZ administration, the total serum bilirubin of dogs in group $B$ was significantly $(p<0.05)$ higher than those in groups A, C and D. However, days 14, 21 and 28 , both total and direct bilirubin concentration in dogs in group $C$ were significantly $(p<0.05)$ higher than those of group $A, B$ and $D$.

\section{Effects of 21 days ceftriaxone administration on kidney functions in dog}

The effects of ceftriaxone administration on kidney function tests in dogs are shown in Table 4. On days 14 and 21 , the serum creatinine and blood urea nitrogen levels of dogs in group $C$ was significantly $(p<0.05)$ lower when compared to other groups. However, on days 14 and 21, the serum uric acid level of dogs in group $C$ was significantly $(p<0.05)$ higher than those of group $A, B$ and $D$.

\section{DISCUSSION}

The clinic-toxicological effects of intramuscular administration of graded doses of ceftriaxone were investigated in normal dogs. Ceftriaxone at $50 \mathrm{mg} / \mathrm{kg}$ produced toxic effects including diarrhea, mucopurulent eye discharge and paralysis of the hind limb from the second week of treatment in dogs. These side effects observed in dogs receiving $50 \mathrm{mg} / \mathrm{kg}$ of CFZ corroborates the findings of Eke et al [8], that the potential for toxicity of CFZ in dogs increases as the dose increases. The pale mucous membrane observed in this study may be due to anaemia which was also a side effect reported in humans treated with CFZ [11].

The diarrhea observed in this study may be attributed to prolong use of the antibiotic probably due to disturbance of the gut microflora. This is similar to what was observed in mares where gastrointestinal disturbances including severe colitis were noted with CFZ administration [12]. One out of the 4 dogs in group C $(50 \mathrm{mg} / \mathrm{kg})$ developed signs of central nervous involvement such as bilateral paralysis of the hindlimbs on day 21 until the experiment was terminated on day 28 . The most curious observation was hair loss (hair pulling) not alopecia as observed in all the dogs but more prominent in the dogs that received $50 \mathrm{mg} / \mathrm{kg}$ ceftriaxone on days 21 and 28. However there was no alopecia and this could mean that the hair was regenerating fast which could be related to anabolic effects of CFZ.

The effect of CFZ on the haematological studies in dogs showed that it caused significant $(p<$ 0.05) decrease in RBC, PCV and HB concentration in all the treated groups. However, this reduction reversed in dogs in groups $A(12.5$ $\mathrm{mg} / \mathrm{kg})$ and $B(25 \mathrm{mg} / \mathrm{kg})$ after the treatment was 
Table 3: Effects of experimental ceftriaxone administration on liver enzymes activities in dogs

\begin{tabular}{|c|c|c|c|c|}
\hline \multirow[t]{2}{*}{ Parameter } & \multicolumn{4}{|c|}{ Days of ceftriaxone administration } \\
\hline & 7 & 14 & 21 & 28 \\
\hline \multicolumn{5}{|l|}{$A L T(I U / L)$} \\
\hline A & $18.69 \pm 1.11^{a}$ & $18.38 \pm 1.01^{a}$ & $28.09 \pm 1.49^{a}$ & $41.94 \pm 6.40^{a}$ \\
\hline $\mathrm{B}$ & $19.61 \pm 1.31^{a}$ & $19.08 \pm 0.98^{a}$ & $35.46 \pm 4.16^{b}$ & $42.38 \pm 3.34^{a}$ \\
\hline C & $23.56 \pm 3.33^{a}$ & $31.35 \pm 0.82^{b}$ & $42.25 \pm 1.23^{b}$ & $41.08 \pm 4.77^{a}$ \\
\hline D & $34.58 \pm 1.62^{b}$ & $34.38 \pm 2.42^{b}$ & $34.08 \pm 2.79^{b}$ & $34.54 \pm 1.42^{b}$ \\
\hline \multicolumn{5}{|l|}{$A L P(I U / L)$} \\
\hline A & $230.3 \pm 6.20$ & $287.9 \pm 2.15^{a}$ & $180.0 \pm 9.07^{\mathrm{a}}$ & $166.5 \pm 2.17^{\mathrm{a}}$ \\
\hline B & $231.0 \pm 2.06$ & $289.5 \pm 4.62^{a}$ & $158.3 \pm 7.60^{a}$ & $157.7 \pm 2.50^{a}$ \\
\hline C & $229.4 \pm 7.68$ & $277.2 \pm 8.81^{a}$ & $201.1 \pm 5.24^{a}$ & $167.5 \pm 9.83^{a}$ \\
\hline D & 238. $1 \pm 2.46$ & $236 \pm 1.43^{b}$ & $233.8 \pm 5.88^{b}$ & $234.9 \pm 9.77^{b}$ \\
\hline \multicolumn{5}{|l|}{ AST (IU/L) } \\
\hline A & $23.74 \pm 0.77$ & $24.74 \pm 0.64^{a}$ & $24.84 \pm 0.55^{a}$ & $23.96 \pm 0.80^{a}$ \\
\hline B & $22.40 \pm 1.06$ & $35.00 \pm 1.49^{b}$ & $38.43 \pm 0.35^{b}$ & $38.15 \pm 0.77^{b}$ \\
\hline C & $24.01 \pm 0.80$ & $38.82 \pm 1.28^{b}$ & $43.68 \pm 1.69^{b}$ & $46.40 \pm 1.43^{b}$ \\
\hline D & $24.29 \pm 0.66$ & $23.83 \pm 0.47^{a}$ & $24.01 \pm 0.74^{a}$ & $23.72 \pm 0.49^{a}$ \\
\hline \multicolumn{5}{|c|}{ Total protein (g/dl) } \\
\hline A & $5.950 \pm 0.10$ & $5.58 \pm 0.09^{a}$ & $6.90 \pm 0.11^{a}$ & $6.55 \pm 0.34^{a}$ \\
\hline B & $5.05 \pm 0.17$ & $5.28 \pm 0.29^{a}$ & $6.33 \pm 0.05^{a}$ & $6.15 \pm 0.39^{a}$ \\
\hline C & $5.67 \pm 0.35$ & $4.07 \pm 1.16^{b}$ & $5.00 \pm 0.35^{b}$ & $5.63 \pm 0.15^{b}$ \\
\hline $\mathrm{D}$ & $5.03 \pm 0.41$ & $5.04 \pm 0.38^{a}$ & $5.03 \pm 0.41^{b}$ & $5.00 \pm 0.42^{b}$ \\
\hline \multicolumn{5}{|c|}{ Albumin (g/dl) } \\
\hline A & $2.64 \pm 0.08$ & $2.88 \pm 0.05^{a}$ & $2.69 \pm 0.12^{a}$ & $2.86 \pm 0.12$ \\
\hline B & $2.51 \pm 0.18$ & $2.72 \pm 0.11^{a}$ & $2.95 \pm 0.11^{a}$ & $2.57 \pm 0.24$ \\
\hline C & $2.66 \pm 0.04$ & $1.39 \pm 0.17^{b}$ & $1.85 \pm 0.42^{b}$ & $2.01 \pm 0.13$ \\
\hline $\mathrm{D}$ & $2.24 \pm 0.28$ & $2.18 \pm 0.25^{a}$ & $2.28 \pm 0.26^{a}$ & $2.28 \pm 0.27$ \\
\hline \multicolumn{5}{|c|}{ Globulin (g/dl) } \\
\hline A & $2.74 \pm 0.02^{a}$ & $3.70 \pm 0.10^{a}$ & $4.21 \pm 0.11^{a}$ & $4.37 \pm 0.33^{a}$ \\
\hline B & $2.73 \pm 0.01^{a}$ & $3.55 \pm 0.27^{a}$ & $3.38 \pm 0.13^{a b}$ & $3.47 \pm 0.20$ a b \\
\hline $\mathrm{C}$ & $1.76 \pm 0.05^{\mathrm{b}}$ & $1.58 \pm 0.27^{b}$ & $3.12 \pm 0.05 \mathrm{ab}$ & $3.08 \pm 0.05$ a b \\
\hline $\mathrm{D}$ & $2.75 \pm 0.03^{a}$ & $2.78 \pm 0.05^{a}$ & $2.79 \pm 0.01^{b}$ & $2.80 \pm 0.01 b$ \\
\hline \multicolumn{5}{|c|}{ Total bilirubin $(\mathrm{mg} / \mathrm{dl})$} \\
\hline A & $0.16 \pm 0.02^{a}$ & $0.17 \pm 0.02^{a}$ & $0.20 \pm 0.03^{a}$ & $0.16 \pm 0.03^{a}$ \\
\hline B & $0.23 \pm 0.02^{b}$ & $0.22 \pm 0.03^{a}$ & $0.19 \pm 0.04^{a}$ & $0.22 \pm 0.05^{a}$ \\
\hline C & $0.17 \pm 0.01^{a}$ & $0.39 \pm 0.02^{b}$ & $0.45 \pm 0.07^{b}$ & $0.38 \pm 0.05^{b}$ \\
\hline $\mathrm{D}$ & $0.13 \pm 0.01^{a}$ & $0.14 \pm 0.01^{a}$ & $0.14 \pm 0.01^{a}$ & $0.13 \pm 0.01$ \\
\hline \multicolumn{5}{|c|}{ Direct bilirubin ( $m g / d l)$} \\
\hline A & $0.06 \pm 0.00$ & $0.05 \pm 0.01$ & $0.05 \pm 0.01$ & $0.06 \pm 0.01$ \\
\hline B & $0.05 \pm 0.01$ & $0.04 \pm 0.01$ & $0.05 \pm 0.02$ & $0.07 \pm 0.01$ \\
\hline C & $0.07 \pm 0.02$ & $0.11 \pm 0.04$ & $0.13 \pm 0.03$ & $0.15 \pm 0.01$ \\
\hline D & $0.08 \pm 0.01$ & $0.08 \pm 0.01$ & $0.08 \pm 0.01$ & $0.07 \pm 0.00$ \\
\hline
\end{tabular}

Values on the same column with different superscripts vary significantly $p<0.05 ; A: 12.5 \mathrm{mg} / \mathrm{kg}$ of ceftriaxone; $B$ : 25mg/kg of ceftriaxone; C: $50 \mathrm{mg} / \mathrm{kg}$ of ceftriaxone; D: control group

stopped, but not in group C $(50 \mathrm{mg} / \mathrm{kg})$. The decrease in these parameters may be as a result of CFZ induced anaemia. CFZ has been known to be the second most common drug that induces immune-haemolytic anaemia which is highly fatal in children and adult receiving the drug for more than 1 week $[3,11]$. The anaemia usually develops gradually over 7 to 10 days and reverses over a couple of weeks after the ceftriaxone drug is withdrawn. However, anaemia did not reverse one week after treatment was stopped in the group receiving $50 \mathrm{mg} / \mathrm{Kg} \mathrm{CFZ}$. This suggests that dogs receiving the $50 \mathrm{mg} / \mathrm{kg}$ dose or higher of CFZ may be at risk of developing aplastic anaemia [13]. Nevertheless, biopsy of the bone marrow was not done to determine if the bone marrow was really suppressed, although the significant decrease in leucocyte count in dogs in group $C$ not reversed on stoppage of treatment could suggest the condition. Cephalosporins such as cefroxadine and CFZ have been identified as drugs that could cause aplastic anaemia in humans [13]. In this study, there was significant $(p<0.05)$ reduction in the mean total white blood cell, neutrophil and lymphocyte count of dogs in group $\mathrm{C}$ from day 14 until the experiments ended on day 28 . This observation corroborates the neutropaenia observed in a patient suffering from pneumonia who received CFZ for 11 days [14].

It was observed in this study that CFZ caused a transient tachycardia immediately after administration, but was normalized an hour post treatment. There was also significant increase in the heart and pulse rate particularly in dogs that 
Table 4: Effect of experimental ceftriaxone administration on the kidney functions in dogs

\begin{tabular}{|c|c|c|c|c|}
\hline \multirow[t]{2}{*}{ Parameter } & \multicolumn{4}{|c|}{ Days of ceftriaxone administration } \\
\hline & 7 & 14 & 21 & 28 \\
\hline \multicolumn{5}{|c|}{ Creatinine (mg/dl) } \\
\hline A & $0.83 \pm 0.01$ & $0.87 \pm 0.10^{a}$ & $0.87 \pm 0.06^{a}$ & $0.86 \pm 0.06$ \\
\hline B & $0.78 \pm 0.06$ & $0.80 \pm 0.08^{a}$ & $0.68 \pm 0.07^{\mathrm{a}}$ & $0.69 \pm 0.09$ \\
\hline C & $0.72 \pm 0.08$ & $0.32 \pm 0.11^{\mathrm{b}}$ & $0.37 \pm 0.10^{b}$ & $0.67 \pm 0.15$ \\
\hline D & $0.77 \pm 0.03$ & $0.76 \pm 0.02^{a}$ & $0.78 \pm 0.03^{a}$ & $0.77 \pm 0.02$ \\
\hline \multicolumn{5}{|c|}{ Blood urea nitrogen (BUN) (mg/dl) } \\
\hline A & $26.62 \pm 1.68$ & $30.96 \pm 2.3^{a}$ & $30.00 \pm 1.24^{a}$ & $27.76 \pm 1.52$ \\
\hline B & $28.07 \pm 1.60$ & $32.19 \pm 2.87^{a}$ & $32.68 \pm 2.73^{a}$ & $33.10 \pm 2.77$ \\
\hline C & $25.33 \pm 1.01$ & $21.39 \pm 3.39^{b}$ & $22.61 \pm 3.08^{b}$ & $28.47 \pm 4.22$ \\
\hline $\mathrm{D}$ & $27.98 \pm 0.48$ & $28.00 \pm 0.49^{a}$ & $28.02 \pm 0.50^{a}$ & $27.99 \pm 0.48$ \\
\hline \multicolumn{5}{|c|}{ Uric acid (mg/dl) } \\
\hline A & $0.39 \pm 0.03$ & $0.39 \pm 0.02^{a}$ & $0.46 \pm 0.05^{a}$ & $0.33 \pm 0.04$ \\
\hline B & $0.44 \pm 0.07$ & $0.56 \pm 0.08^{a}$ & $0.53 \pm 0.16^{a}$ & $0.36 \pm 0.04$ \\
\hline C & $0.44 \pm 0.02$ & $0.96 \pm 0.15^{b}$ & $0.92 \pm 0.08^{b}$ & $0.36 \pm 0.05$ \\
\hline $\mathrm{D}$ & $0.57 \pm 0.04$ & $0.56 \pm 0.02^{a}$ & $0.56 \pm 0.03^{a}$ & $0.56 \pm 0.04$ \\
\hline
\end{tabular}

received $50 \mathrm{mg} / \mathrm{kg}$ of CFZ. This observed tachycardia may be a compensatory response by the heart to hypoperfusion of tissues due to anaemia, also the non-significant slight increase in the mean respiratory rate of dogs in the same group showed that there was a compensation of the lungs to hypoxia due to anaemia.

Intramuscular administration of ceftriaxone caused significantly $(p<0.05)$ decrease in activity of ALT on days 7 in all the treated groups; an indication of the stability and protection of the membrane of the hepatocytes. However, on day 14 , there was significant ( $p<$ 0.05) increase in ALT activity in dogs that received $50 \mathrm{mg} / \mathrm{kg}$ when compared to the groups $A$ and $B$. However, on day 21 , the ALT activity of the treated group increased and persisted 7 days (day 28) post treatment. This finding showed the potential of CFZ to cause hepatocellular injury, in other words, lower doses (12.5 and $25 \mathrm{mg} / \mathrm{kg}$ ) protected the liver for 2 weeks, while the higher dose $(50 \mathrm{mg} / \mathrm{kg}$ ) had one-week hepatoprotective effects following administration, at the end of which, all doses (low and high) became hepatotoxic and caused hepatocellular injury.

Studies have shown that elevated activities of these cytosolic enzymes indicate hepatocyte or other cell type damage [15]. However, the ALT is more specific to liver and better use in the diagnosis of liver injury particularly in dogs and cats [16]. Similarly, the activity of AST was elevated from day 14 in groups B and C, which continued throughout the period of study, indicative of hepatoxicity. Although, the sources of serum AST are liver, heart, and skeletal muscle and elevated levels of activities may be attributed to the damage to any of these organs [17]; however, in this study, it may be safe to say that its elevation indicates an acute hepatocellular injury. The activity of ALP was significantly elevated on day 14 of treatment and then significantly decreased on days 21 and 28 . This further confirmed that there was liver damage. Alkaline phosphatase (ALP) is an inducible enzyme which determines the patency of the biliary system, found mainly in bone and liver and in small amounts in kidneys and the gastrointestinal tract [18].

The source of normal serum ALP activity is the liver because the half-life of ALP from other sources are usually less than 6 minutes and may not cause increased serum ALP activity [19]. Consequently, an elevation of ALP is associated with liver disease particularly in early phase of obstructive jaundice.

Conversely to the effect on the liver, CFZ induced significant $(p<0.05)$ increase in total protein, albumin and globulin, an indication of anabolic effect particularly at the doses of 12.5 and $25 \mathrm{mg} / \mathrm{kg} \mathrm{CFZ}$. But at the dose of $50 \mathrm{mg} / \mathrm{kg}$ CFZ there was a significant decrease in total protein, albumin and globulin levels which may be attributed to catabolism. The liver is also involved in the synthesis of proteins probably enzymes, and or immunoglobulins which maintain oncotic (osmotic) integrity, transportation of drugs and nutrients [20]. Furthermore, anabolic effect of CFZ observed at a lower dose was reflected in albumin and globulin. Both were significantly $(p<0.05)$ elevated on days 14,21 and 28 at 12.5 and 25 $\mathrm{mg} / \mathrm{kg}$ ceftriaxone. Administration of $50 \mathrm{mg} / \mathrm{kg}$ CFZ significantly $(p<0.05)$ decreased serum albumin and globulin level, it was not significantly $(p>0.05)$ different from the control on days 14 and 21 . These findings showed that the synthetic 
function of the liver was compromised at the dose of $50 \mathrm{mg} / \mathrm{kg}$ CFZ. In this study, $50 \mathrm{mg} / \mathrm{kg}$ CFZ significantly $(p<0.05)$ increased the level of total and direct bilirubin which started from day 14 and lasted throughout the duration of the study. This effect could be due to hepatocellular damage coupled with impaired excretory and secretory functions of the liver. Bilirubin as a product of hemoglobin degradation during the apoptosis of erythrocyte is affected by the rate of erythrocyte destruction, the functional capacity of the liver and rate of bilirubin excretion [21]. Ceftriaxone has been previously reported to cause cholestatic jaundice [22]. Therefore, it can be deduced that the anaemia observed in this study may be due to haemolysis because of the hyperbilirubinaemia and brownish colouration of urine observed in the treated groups.

All doses of ceftriaxone caused significant increase in BUN level throughout the duration of the experiment. Elevated BUN and creatinine levels are indicative of abnormal renal function [23]. Ceftriaxone (12.5 and $25 \mathrm{mg} / \mathrm{kg}$ ) caused significant elevation of serum creatinine on days 14 and 21 , while $50 \mathrm{mg} / \mathrm{kg}$ ceftriaxone depleted serum creatinine. Intramuscular administration of ceftriaxone for 21 days caused dose-dependent decrease in uric acid which was significant at the dose in all treated groups on the $14^{\text {th }}$ and $21^{\text {st }}$. On $28^{\text {th }}$ day of observation, the level of uric acids of the treated groups was significantly lower than those of the control group. Uric acid is end product of purine metabolism and it is cleared from the plasma by glomerular filtration and perhaps by tubular secretion [24]. It may not be an important marker for kidney function but its elevation is a sign of oxidative stress [24].

\section{CONCLUSION}

The 21-day intramuscular administration of graded doses of ceftriaxone at the dose of 50 $\mathrm{mg} / \mathrm{kg}$ in normal Basenji dogs causes liver damage, nephrotoxicity anaemia, leucopaneia, tachycardia, and bilateral paralysis of the hind limbs. Care should be taken in the administration of ceftriaxone over a prolonged period of time as it could lead to several adverse reactions. Thus, irrespective of the dose of ceftriaxone adopted for use in the treatment of dogs, duration plays a key role as most of the adverse reactions start after 14 days in lower doses and 7 days at 50 $\mathrm{mg} / \mathrm{kg}$.

\section{DECLARATIONS}

\section{Conflict of Interest}

No conflict of interest associated with this work.

\section{Contribution of Authors}

The authors declare that this work was done by the authors named in this article and all liabilities pertaining to claims relating to the content of this article will be borne by them.

\section{Open Access}

This is an Open Access article that uses a funding model which does not charge readers or their institutions for access and distributed under the terms of the Creative Commons Attribution License (http://creativecommons.org/licenses/by/ 4.0) and the Budapest Open Access Initiative (http://www.budapestopenaccessinitiative.org/rea d), which permit unrestricted use, distribution, and reproduction in any medium, provided the original work is properly credited.

\section{REFERENCES}

1. Christian SS, Christian JS. The cephalosporins antibiotics. Prim Care Update OB/GYNS 1997; 4: 168 174.

2. Lin HA, Yang YS, Wang JX, Lin HC, Lin DY, Chiu CH, Yeh KM, Lin JC, Chang FY. Comparison of the effectiveness and antibiotic cost among ceftriaxone, ertapenem, and levofloxacin in treatment of communityacquired complicated urinary tract infections. J Microbiol Immunol Infect 2016; 49: 237-242.

3. De Wilde M, Speeckaert M, Callens R, Van Biesen W. Ceftriaxone-induced immune hemolytic anemia as a lifethreatening complication of antibiotic treatment of 'chronic Lyme disease. Acta Clin Belg 2017; 72 (2): 133137.

4. Longo F, Hastier P, Buckley MJM, Chichmanian RM, Delmont J. Acute hepatitis, autoimmune hemolytic anemia, and erythroblastocytopenia induced by ceftriaxone. The Am J gastroenterol 1998; 93(5): 836837.

5. Plumb DC. Ceftriaxone Sodium. Veterinary Drug Handbook, 3rd Edition. (Pharma Vet. Publishing, MN, USA) 1999; 111-112.

6. Colakoglu EC, Haydardedeoglu AE, Alihosseini H, Hayirli A. Efficacy of single-dose ceftriaxone versus multipledose enrofloxacin in dogs with uncomplicated lower urinary tract infection: a randomised clinical trial. Vet Med (Praha), 2017; 62 (03): 125-130.

7. NIH. Guide for the Care and Use of Laboratory Animals. National Academy Press, Washington, DC, USA. 1996

8. Eke IG, Eze UU, Anaga AO, Chah KF, Anene BM, Asuzu IU. Disposition kinetics of ceftriaxone and determination of its therapeutic dose in dogs. Trop. J. Pharm. Res 2020; 19 (8): 1753-1758

9. Thrall MA, Weiser MG. Hematology. Pages $29-74$. In: Hendrix, C. M. (Ed.), Laboratory Procedures for 
Veterinary Technicians, 4th Edition, Mosby Incorporated, Missouri, USA 2002.

10. Higgins $T$, Beutler E, Doumas BT. Measurement of haemoglobin in blood. 514 - 515. In: Burtis CA, Ashwood ER, Bruns DE. (Eds.), Tietz Fundamentals of Clinical Chemistry, 6th Edition, Saunders Elsevier, Missouri 2008.

11. Denish D, Dugan N, Carter J. Intravascular haemolysis in patient on ceftriaxone with demonstration of anticeftriaxone antibody. Intern. Med. J 2008; 38 (6): 438-41.

12. Gardner SY, Aucoin DP. Pharmacokinetics of ceftriaxone in mares. J Vet Pharmacol Ther. 1994; 17(2): 155-6.

13. Bandhala RM, Anil B, Gopal KB. Ceftriaxone induced aplastic anaemia: A dreadful trap for bone marrow. Br. J. Clin. pharmacol 2019; 85: 8.

14. Gulerva VS, Dhilon M, Gill S, Naithani N. Ceftriaxone induced drug rash with eosinophilia and systemic symptoms. J Res Pharm Pract 2014; 3(2): 72-74.

15. Diaz-Juarez JA, Hernandez-Munoz R. Rat liver enzyme release depends on blood flow-bearing physical forces acting in endothelium glycocalyx rather than on liver damage. Oxid Med Cell Longev 2017; 21: 23-27.

16. Tennant BC. Hepatic function. In: Kaneko JR, Harvey JW, Bruss ML. Clinical Biochemistry of Domestic Animals. 6th Edition. Elsevier Inc., USA 1999; 337-338.

17. Gowda S, Desai PB, Hull VV, Math AAK, Vernekar SN, Kulkarni SS. A review of laboratory function tests. Pan Afri. Med J 2009; 3: 4-7.
18. Alvarez L, Whittemore J. Liver enzyme elevations in dogs: diagnostic approach. Compend Contin Educ Vet 2009; 31(9): 416-8.

19. Thrall MA, Weiser G, Allison R, Campbell TW. Veterinary Hematology and Clinical Chemistry. John Wiley and Sons 2012.

20. Meller N, Jergensen JOL. Effect of growth hormone on glucose, lipid and protein metabolism in human subjects. Endocr. Rev 2009; 30(2): 152-177.

21. Jeney V, Ramos S, Bergman ML, Bechmann I, Tischer J, Ferreira A, Soares MP. Control of disease tolerance to malaria by nitric oxide and carbon momoxide. Cell Rep 2014; 8(1): 129-136.

22. Kaur I, Singh J. Cholestatic hepatitis with intravenous ceftriaxone. Indian J pharmacol 2011; 43(4): 474-475.

23. Sood MM, Saeed M, Lim V, Cordova F, Komenda P, Mailik $A$. The urea to creatinine ratio is predictive of worsening kidney function in ambulatory heart failures patients. J Card Fail 2015; 21(5): 412-418.

24. Spiga R, Maria AM, Mancuso E, Fatta $C D$, Fuoco $A$, Perticone F, Anderozzi F, Mannino GC, Sesti G. Uric acid is associated with inflammatory Biomarkers and induces inflammation via activating the NF-kB signaling pathway in HepG2 cells. Artheroscler, Thromb. Vasc. Biol 2017; 37: 1241-1249. https://doi/10.1161/ATVBAHA.117.309128 